\title{
Perbandingan Metode Deep Residual Network 50 dan Deep Residual Network 152 untuk Deteksi Penyakit Pneumonia pada Manusia
}

\author{
RIFQI RIZQULLAH EKA PRASETYO, MUHAMMAD ICHWAN \\ Program Studi Informatika, Institut Teknologi Nasional Bandung \\ Email: ikiwriz17@gmail.com
}

Received 7 Agustus 2021 | Revised 1 November 2021 | Accepted 25 November 2021

\begin{abstract}
ABSTRAK
Pneumonia merupakan salah satu masalah Kesehatan yang sering dijumpai dan mempunyai dampak yang signifikan di seluruh dunia. Insiden pneumonia dilaporkan meningkat sesuai dengan bertambahnya usia. Pneumonia merupakan diagnosis terbanyak ketiga. Dalam penelitian ini penulis mengidentifikasi citra paru-paru dalam bentuk citra x-ray dengan metode ResNet-50 dan ResNet-152 sebagai ekstrasi ciri dan klasifikasinya. Performa sistem diukur berdasarkan nilai akurasi, presisi, recall, dan f-measure. Eksperimen dilakukan pada dataset paruparu dengan menggunakan dua metode tersebut dan didapatkan akurasi terbaik pada ResNet-152. Hasil menunjukkan nilai rata-rata terbaik accuracy 89,3\%, precision $88,8 \%$, recall $89,6 \%$, dan f-measure $89 \%$. Hasil tersebut dipengaruhi oleh jumlah dataset dari citra training, citra validation, dan citra uji.
\end{abstract}

Kata kunci: Penumonia, Deep Residual Network, RESNET-50, RESNET-152

\begin{abstract}
Pneumonia is one of the most common health problems and has a significant impact throughout the world. The incidence of pneumonia is reported to increase with age. Pneumonia is the third most common diagnosis. In this study, the authors identified lung images in the form of $x$-ray images using the ResNet-50 and ResNet-152 methods as feature extraction and classification. System performance is measured based on the values of accuracy, precision, recall, and $f$-measure. Experiments were carried out on lung datasets using these two methods and the best accuracy was obtained on ResNet-152. The results show the best average value for accuracy is $89.3 \%$, precision is $88.8 \%$, recall is $89.6 \%$, and $f$-measure is $89 \%$. These results are influenced by the number of datasets from training images, validation images, and test images.
\end{abstract}

Keywords: Penumonia, Deep Residual Network, RESNET-50, RESNET-152 


\section{PENDAhUlUAN}

Pneumonia adalah infeksi pada ujung bronkiolus dan alveolus dan infeksi yang paling sering menyebabkan kematian secara terus-menerus, penyakit terbatas dibandingkan dengan populasi yang menyebabkan penundaan berturut-turut dalam pemberian untuk pasien pneumonia. Pneumonia sangat mungkin merupakan masalah medis yang paling dikenal luas dan memiliki efek kritis di seluruh dunia, terutama pada populasi yang lebih tua. Convolutional Neural Organization (CNN) adalah salah satu pengaturan dalam melakukan karakterisasi terprogram pada gambar sinar-X (Maysanjaya, 2020). CNN adalah perhitungan pembelajaran mendalam yang dapat mengambil semua sendiri dari kasus-kasus masa lalu. Apalagi dari pemeriksaan yang telah dilakukan, hasilnya menunjukkan bahwa CNN dapat mendeteksi pneumonia dengan kecepatan pencapaian normal di atas $90 \%$. Ketepatan yang dikembangkan lebih lanjut diperoleh dengan mendorong perhitungan CNN baik melalui penentuan harga barang atau pekerjaan aktuasi yang berpotensi (Jimmi Lin, 2021).

Pengelompokan gambar memiliki banyak pekerjaan. Ini sangat baik dapat digunakan untuk mengenali berbagai daerah tergantung pada jenis penggunaan lahan. Informasi penggunaan lahan digunakan secara luas untuk persiapan metropolitan. Simbolisme tujuan tinggi juga digunakan selama peristiwa bencana seperti banjir, gunung berapi, dan musim kemarau yang serius untuk melihat efek dan bahaya (Vance et al., 2016).

Peningkatan desain CNN dipengaruhi oleh kontes ILSVRC (ImageNet Huge Scope Visual Acknowledgment Rivalry) yang diadakan setiap tahun oleh ImageNet yang merupakan norma dalam pengakuan artikel benchmark. Di pihak oposisi, penilaian tingkat kesalahan dari setiap perhitungan CNN diselesaikan untuk mengenali protes dan mengkarakterisasi gambar untuk cakupan yang sangat besar. Pada tahun 2012 rekayasa CNN bernama AlexNet memiliki kecepatan kesalahan $16,4 \%$ dan menjadikannya juara tahun ini (Feriawan \& Swanjaya, 2020). Kemudian, pada saat itu, pada tahun 2013 dengan kode Clarifai bisa menang dengan kecepatan kesalahan $11,7 \%$. Kemudian, pada saat itu, teknik VGG dengan jumlah 19 lapisan menemukan cara untuk mengurangi nilai kesalahan menjadi 7,3\%. Dengan desain GoogLeNet jumlah 22 lapisan dengan kecepatan kesalahan hanya 6,7\% berhasil menjadi juara pada tahun 2014. Juara oposisi pada tahun 2015 dengan ResNet engineering dari Microsoft memperluas penggunaan lapisan hingga 152. lapisan yang menemukan cara untuk mengurangi nilai kesalahan hingga 3,57\%. Kecepatan kesalahan desain DenseNet sebesar 5,17\%. Meskipun mendapatkan nilai kesalahan sebesar 3,57\% namun lapisan yang digunakan dalam rekayasa ResNet adalah 152 lapisan, tugas komputasi yang diperlukan lebih tinggi dari sebelumnya. Sehingga desain GoogLeNet dapat menjadi rekayasa keputusan untuk melakukan pengenalan objek dengan presisi tinggi namun tidak memerlukan tugas komputasi yang tinggi seperti rekayasa ResNet (Russakovsky et al., 2015).

Perhitungan CNN sering digunakan oleh para ahli untuk mengidentifikasi suatu item, karena perhitungan ini telah diakui sebagai model perhitungan terbaik dalam menangani masalah pengenalan artikel (Eka Putra, 2016). Model CNN yang berbeda diusulkan oleh beberapa ahli termasuk LeNet, AlexNet, ZFNet, GoogleNet, VGGNet, dan ResNet (Hakim, 2018). ResNet engineering dapat mengalahkan struktur yang berbeda dalam mengatur gambar pada dataset ImageNet dengan tingkat ketepatan yang signifikan mencapai 80,62\%. Juga, memiliki beberapa struktur berbeda seperti AlexNet, GoogleNet, dan VGGNet (Munir et al., 2019).

Pada penelitian yang di lakukan oleh (Gao et al., 2020) mengarahkan pemeriksaan untuk mengenali epilepsi menggunakan strategi Convolutional Neural Organization yang 
menciptakan kecepatan ketepatan normal 92\% dan dalam eksplorasi dipimpin (Yousif et al., 2018) mengarahkan eksplorasi untuk membedakan (tidak berbahaya) dan berbahaya (mengancam) penyimpangan dari gambar otak sinar- $X$ menggunakan organisasi saraf backpropagation. Teknik backpropagation mempersiapkan organisasi untuk mendapatkan keselarasan antara mempersiapkan dan menguji organisasi. Ketepatan penyiapan backpropagation yang paling tinggi adalah 88,89\% dari 9 informasi penyiapan.

Melihat gambaran masalah yang digambarkan di atas, eksplorasi yang diarahkan oleh pencipta adalah untuk membangun kerangka kerja pengaturan pneumonia manusia dengan menggunakan strategi CNN. Karena ada berbagai jenis desain yang dapat digunakan dalam strategi CNN, dalam tinjauan ini model komposisi yang digunakan adalah ResNet50 dan Resnet152 untuk melihat dan menemukan nilai terbaik pada dengan alasan bahwa di masa lalu ujian hanya menggunakan salah satunya dan belum bisa melihat yang terbaik. Pemeriksaan ini diandalkan untuk memberikan hasil terbaik sehingga cenderung digunakan untuk membantu para ahli klinis dalam membedah pneumonia pada manusia. Konsekuensi dari temuan pneumonia dapat membantu dalam menentukan jenis pengobatan yang tepat untuk individu dengan pneumonia, untuk membatasi angka kematian di Indonesia. Selain itu, eksplorasi ini juga dapat membantu upaya otoritas publik untuk mengikuti dan bekerja pada kesejahteraan umum.

\section{METODE PENELITIAN}

\subsection{Convolutional Neural Network}

Convolutional Neural Organization (CNN) ditujukan untuk menangani informasi yang berupa cluster sebanyak-banyaknya, misalnya gambar bayangan yang terdiri dari pameran 2D yang berisi piksel dalam tiga nada, khususnya Merah, Hijau, dan Biru. Ada berbagai jenis CNN: 1D untuk tanda dan pengaturan biasanya digunakan untuk bahasa, 2D untuk gambar atau suara; dan 3D untuk rekaman atau gambar volumetrik (LeCun et al., 2015). Convolutional Neural Organization (CNN) adalah kemajuan dari strategi Multi-facet Perceptron (MLP) yang dikenang untuk Residual Network karena kedalaman lapisan yang berbeda dan umumnya diterapkan pada informasi gambar. Pembelajaran mendalam dipisahkan menjadi tiga klasifikasi pendekatan, yaitu pembelajaran yang diatur secara spesifik, pembelajaran tanpa bantuan, dan pembelajaran pendukung. Salah satu kemungkinan pembelajaran yang mendalam adalah untuk menggantikan elemen buatan tangan dengan perhitungan mahir untuk pembelajaran progresif tunggal (tanpa bantuan highlight) atau Semi-dikelola termasuk pembelajaran (semi-teratur) dan berbagai ekstraksi sorotan berjenjang (termasuk ekstraksi)

(Schmidhuber et al., 2014). Model CNN secara efektif diterapkan dengan nama LeNet oleh LeChun dari AT\&T Ringer Labs di Holmdel, New Jersey, AS dalam penelitian tentang pengakuan angka dan huruf. CNN telah mengalahkan strategi AI lainnya seperti SVM, K-NN, dan lainnya dalam urutan objek dalam gambar (Eka Putra, 2016).

\subsection{Arsitektur Residual Network (ResNet)}

Residual Network (ResNet) memenangkan ILSVRC pada tahun 2015. Organisasi ini memungkinkan pembuatan Organisasi Saraf dengan 152 lapisan dan dapat mengurangi kerumitan dibandingkan dengan VGGNet. Tingkat kesalahan yang dicapai dari rekayasa ini adalah $3,57 \%$ dengan tujuan dapat mengalahkan presentasi tingkat manusia pada dataset yang diberikan. 


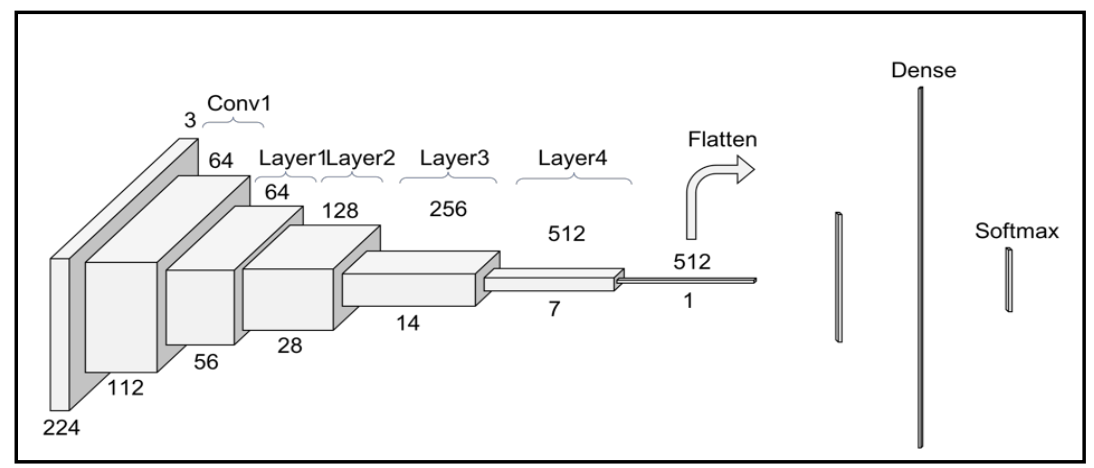

Gambar 1. Contoh Jarinqan ResNet

Sumber : (He et al., 2016)

Deep residual network atau biasa disebut ResNet adalah salah satu struktur CNN yang diusulkan oleh He. pada tahun 2016. Desain ini dibuat untuk mengatasi masalah dengan pemahaman mendalam tentang persiapan, karena fakta bahwa persiapan mendalam secara keseluruhan membosankan dan terbatas pada beberapa lapisan tertentu. Jawaban untuk masalah yang diajukan oleh ResNet adalah dengan menerapkan asosiasi lewati atau rute alternatif. Kelebihan model ResNet dibandingkan dengan model struktural CNN lainnya adalah tampilan model ini tidak berkurang meskipun desainnya semakin maju. Diantaranya ada beberapa layer yang menghasilkan aspek gambar yang lebih sederhana (He et al., 2016) seperti digambarkan pada Gambar 1.

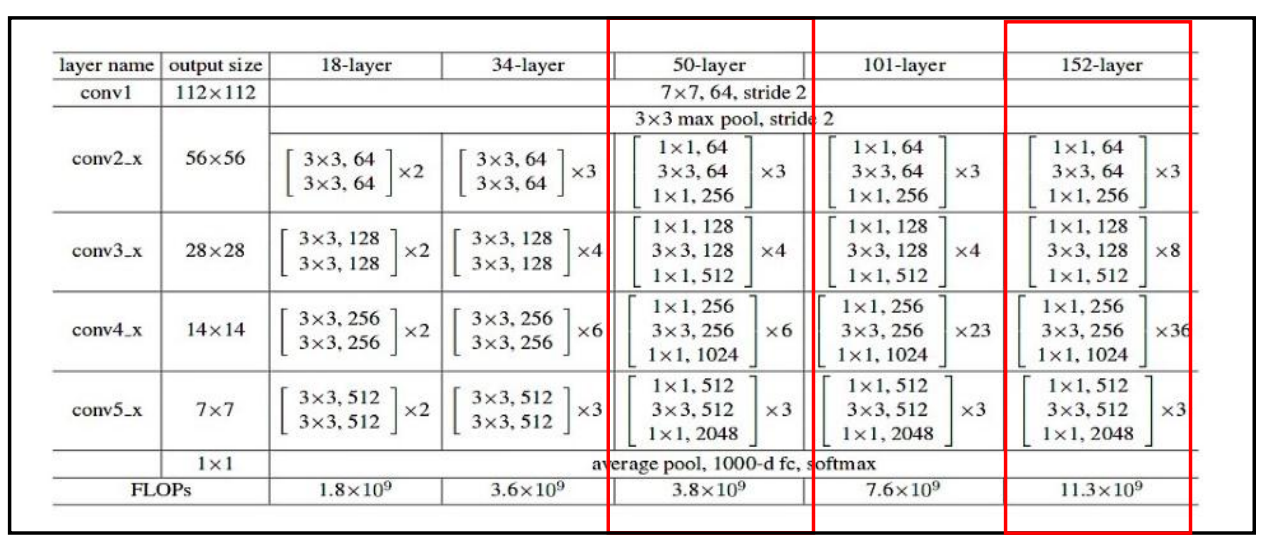

\section{Gambar 2. Arsitektur ResNet}

Sumber : (He et al., 2016)

Untuk resnet50 dimana setiap komposisi lapisan diawali dengan lapisan conv1 berisikan convolution $7 \times 7$ dengan output dimensi 112x112, kemudian lapisan conv2 terdiri dari max pooling 3x3, dan batch normalization $1 \times 1$, ReLU $1 \times 1$ dan convolution $3 \times 3$ proses ini dikalikan $3 x$ menghasilkan output dimensi 56x56. kemudian lapisan conv3 terdiri dari batch normalization 1x1, ReLU $1 \times 1$ dan Convolution $3 \times 3$ proses ini dikalikan 4x menghasilkan output dimensi $28 \times 28$. kemudian lapisan conv4 terdiri dari batch normalization $1 \times 1, R e L U$ $1 \times 1$ dan convolution $3 \times 3$ proses ini dikalikan $6 \times$ menghasilkan output dimensi $14 \times 14$. kemudian lapisan conv5 terdiri dari batch normalization 1x1, ReLU $1 \times 1$ dan convolution 3x3 proses ini dikalikan 3x menghasilkan output dimensi 7x7. kemudian lapisan terakhir terdiri dari avarge max pooling dan softmax menghasilkan output dimensi 1x1 dimana hasil akhir dari arsitektur resnet50. Untuk resnet152 dimana setiap komposisi lapisan diawali dengan 
lapisan conv1 berisikan convolution 7x7 dengan output dimensi $112 \times 112$, kemudian lapisan conv2 terdiri dari max pooling 3x3, dan batch normalization $1 \times 1, R e L U 1 \times 1$ dan convolution $3 \times 3$ proses ini dikalikan 3x menghasilkan output dimensi 56x56. kemudian lapisan conv3 terdiri dari batch normalization 1x1, ReLU 1x1 dan convolution 3x3 proses ini dikalikan 8x menghasilkan output dimensi $28 \times 28$. kemudian lapisan conv4 terdiri dari batch normalization $1 \times 1, \operatorname{ReLU} 1 \times 1$ dan convolution $3 \times 3$ proses ini dikalikan 36x menghasilkan output dimensi 14x14. kemudian lapisan conv5 terdiri dari batch normalization $1 \times 1$, ReLU $1 \times 1$ dan convolution $3 \times 3$ proses ini dikalikan $3 x$ menghasilkan output dimensi $7 \times 7$. kemudian lapisan terakhir terdiri dari avarge max pooling dan softmax menghasilkan output dimensi 1x1 dimana hasil akhir dari arsitektur resnet. Yang diilustrasikan pada Gambar 3.

\subsection{Perancangan Umum}

\subsubsection{Block Diagram}

Dalam penelitian ini ada beberapa tahapan untuk mengidentifikasi citra paru-paru. pada penelitian ini merupakan penelitian yang didasarkan berdasarkan beberapa penelitian yang sudah ada dan berikut ini pada gambar merupakan tahapan secara umum untuk mengidentifikasi citra paru-paru pada Gambar 3.

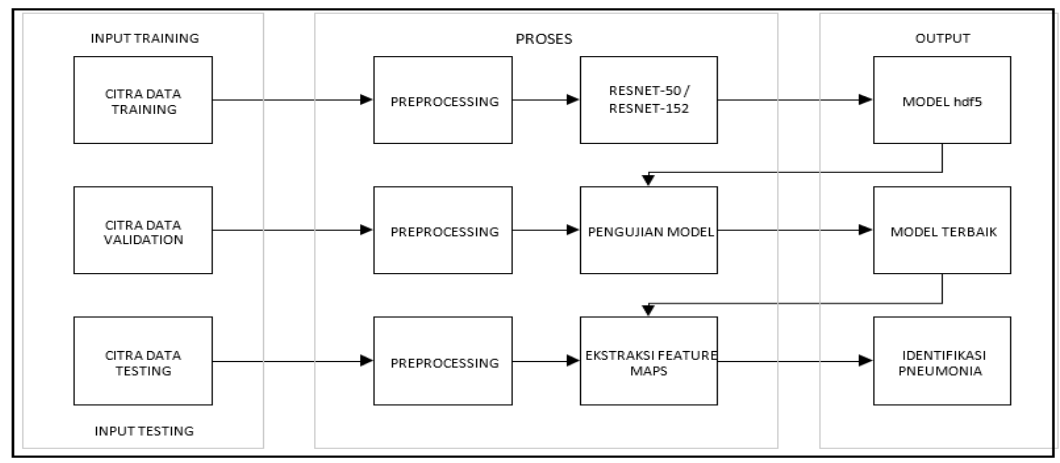

Gambar 3. Block Diagram

Persiapkan data pneumonia untuk melakukan training seperti data training, data validation, dan data testing. Pada input training dilakukan tahapan training yang ada pada data training dengan data validation. Pada tahap proses nya melakukan preprocessing menggunakan resize menjadi $224 \times 224$ piksel dan normalized data sesudah di resize data tersebut. Pada citra data training menggunakan proses dengan model ResNet-50 dan ResNet-152 yang terdapat proses feature extraction dan classification. Pada model ResNet-50 dan ResNet-152 terdapat operasi umum batch normalization, ReLU activation, dan convolution (Halprin Abhirawa, Jondri, 2017). Model ResNet-50 dengan 50 layer dan ResNet-152 dengan 152 layer yang memiliki proses Residual block 1, transition layer 1, Residual block 2, transition layer 2, Residual block 3, transition layer 3, Residual block 4 dan classification layer yang menghasilkan output model dengan format hdf5. Pada data validation proses dilakukan pengujian model dengan data training yang akan menghasilkan output dengan model yang terbaik dalam sisi bobot.

Pada citra data testing masuk kedalam proses preprocessing dengan resize dengan menjadi $224 \times 224$ piksel dan normalized data kemudian melakukan proses ekstraksi feature maps dengan mengambil nilai bobot terbaik dari data training sehingga akan menghasilkan output identifikasi dari pneumonia yang memiliki label 0 untuk normal dan 1 untuk pneumonia. 


\subsubsection{Use Case Diagram}

Pada Gambar 4 terdapat use case diagram dari sistem yang akan dibangun, dan berinteraksi antara aktor atau user dengan sistem. Dimana aktor atau user akan memilih gambar pada sistem sebagai gambar yang akan diuji kemudian aktor atau user dapat melakukan proses identifikasi pneumonia pada manusia yang terdiri dari proses klasifikasi gambar yang didahului oleh preprocessing kemudian masuk kedalam proses arsitektur ResNet-50 dan ResNet-152 pada citra input.

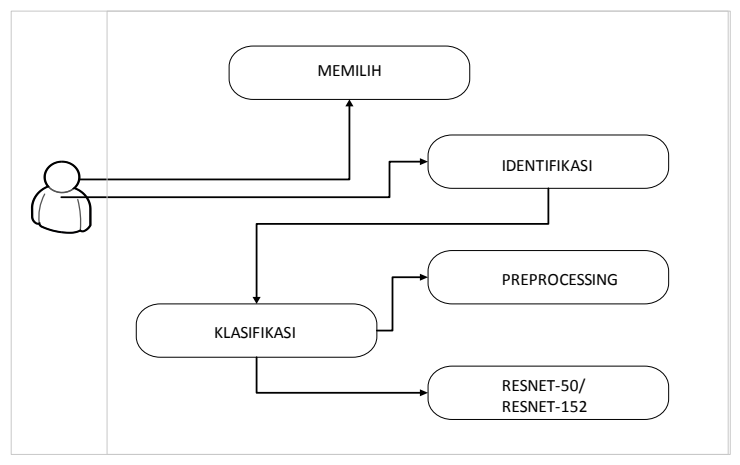

Gambar 4. Use Case Diagram

\subsection{Pembangunan Prototype}

\subsubsection{Pemodelan Sistem}

Pada tahap pemodelan sistem akan menjelaskan tentang user memilih gambar untuk data uji pada direktori dan sistem akan menampilkan hasil identifikasi paru-paru.

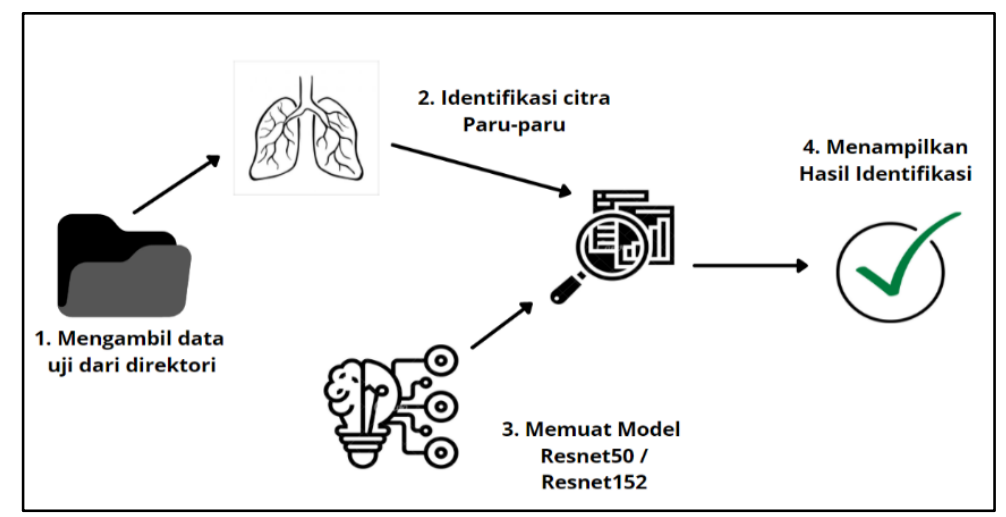

Gambar 5. Model Sistem

Pada Gambar 5 diilustrasikan terdapat 4 langkah proses antara user dengan sistem untuk mengidentifikasi citra paru-paru:

1. Langkah pertama user memilih file gambar yang akan diuji dari direktori.

2. Langkah kedua sistem akan mendeteksi citra paru-paru.

3. Langkah ketiga tersambung dengan langkah kedua adalah load model yang sudah di training menggunakan model ResNet-50 dan ResNet-152 yang berisi bobot dari model tersebut. 
4. Langkah terakhir sistem akan menampilkan hasil dari identifikasi dari gambar yang di masukan oleh user.

\subsubsection{Flowchart}

Pada Gambar 6 diilustrasikan flowchart keseluruhan sistem dalam menentukan identifikasi pneumonia pada manusia. Sistem dimulai dengan input citra atau gambar kemudian melakukan preprocessing kemudian setelah melakukan preprocessing kemudian melakukan operasi convolution $7 \times 7$ dengan strides 2 , operasi dilanjutkan dengan max pooling $3 \times 3$ dengan strides 2 dan akan mendapatkan suatu nilai matriks yang diproses ke operasi Residual block 1, transition layer 1, Residual block 2, transition layer 2, Residual block 3, transition layer 3, Residual block 4 dan kemudian nilai matriks yang sudah diproses oleh operasi sebelum nya di proses kembali pada tahapan classification layer dengan operasi global average pooling $7 \times 7$ dan kemudian softmax activation adalah operasi terakhir dari model ResNet-50 dan ResNet-152 ini untuk menentukan nilai yang mendekati antara 0 dan 1 untuk 0 identifikasi "Normal" dan untuk nilai 1 identifikasi "Pneumonia".

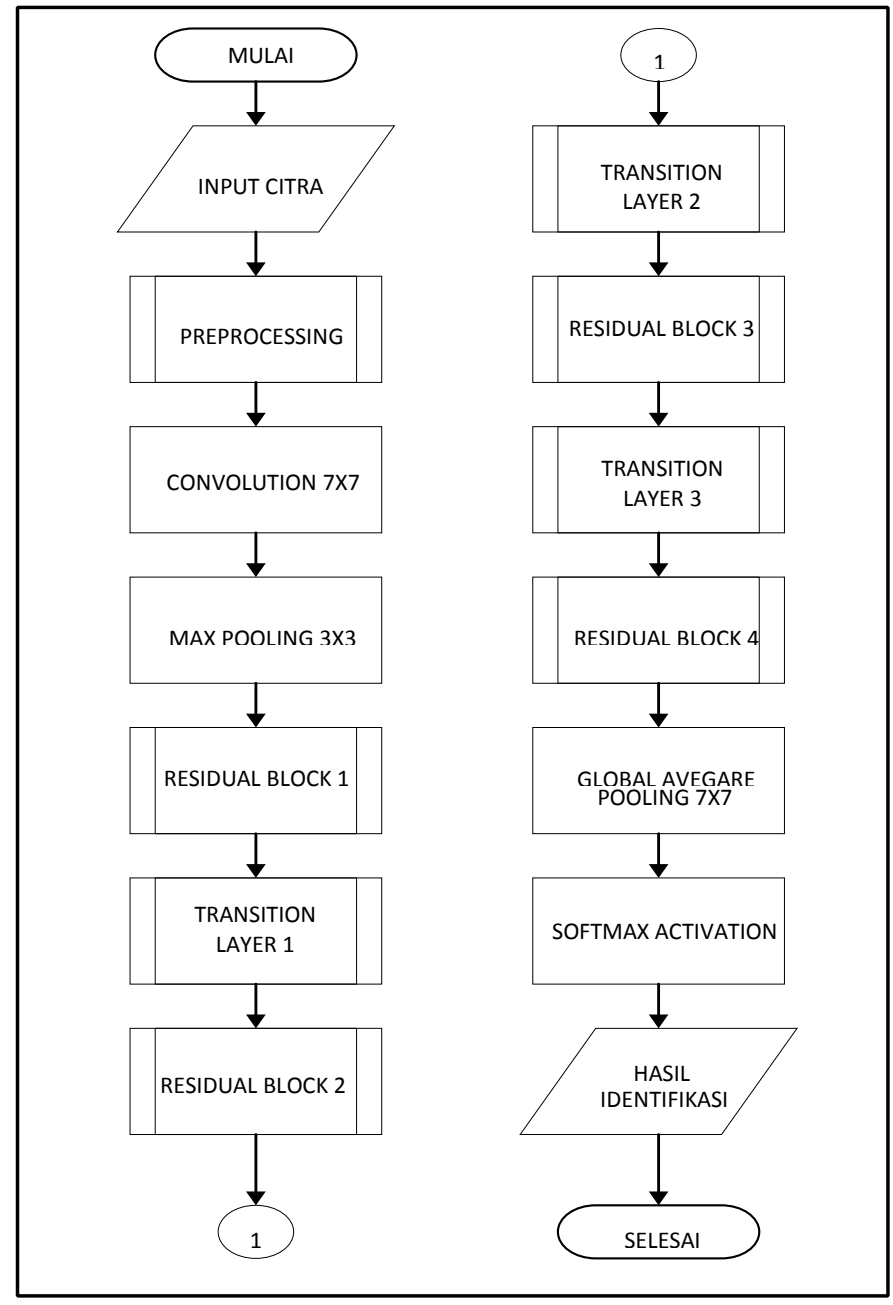

Gambar 6. Flowchart Keseluruhan Sistem

Untuk tahapan sub proses preprocessing seperti Gambar 7 yang diilustrasikan sesudah citra dimasukan ke tahap preprocessing yang berupa ada tahap resize $224 \times 224$ piksel sesudah di resize menjadi $224 \times 224$ piksel citra tersebut di normalized data citra/255 sehingga nilai matriks pada citra tersebut menjadi 0 sampai 1 . 


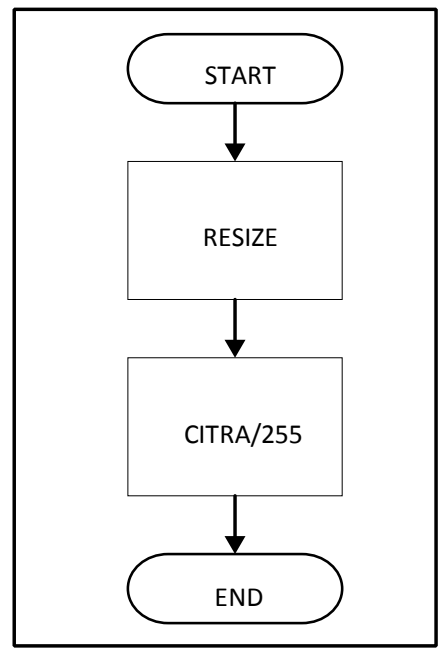

\section{Gambar 7. Flowchart Sub Proses Preprocessing}

Pada Gambar 8 untuk tahap sub proses Residual block terdapat operasi batch normalization, $R e L U$ activation, convolution $1 \times 1$ operasi ini dinamakan bottleneck pada didalam proses Residual block tersebut kemudian operasi selanjutnya batch normalization, ReLU activation, convolution $3 \times 3$ dimana nilai matriks tersebut saling keterhubungan satu sama lain sehingga nilai matriks tersebut digabungkan. Pada proses Residual block terdapat operasi yang dikalikan sehingga mencapai layer 50, Residual block 1 terdapat operasi convolution yang dikalikan 3, Residual block 2 terdapat operasi convolution yang dikalikan 4, Residual block 3 terdapat operasi convolution yang dikalikan 6, dan Residual block 4 terdapat operasi convolution yang dikalikan 3.

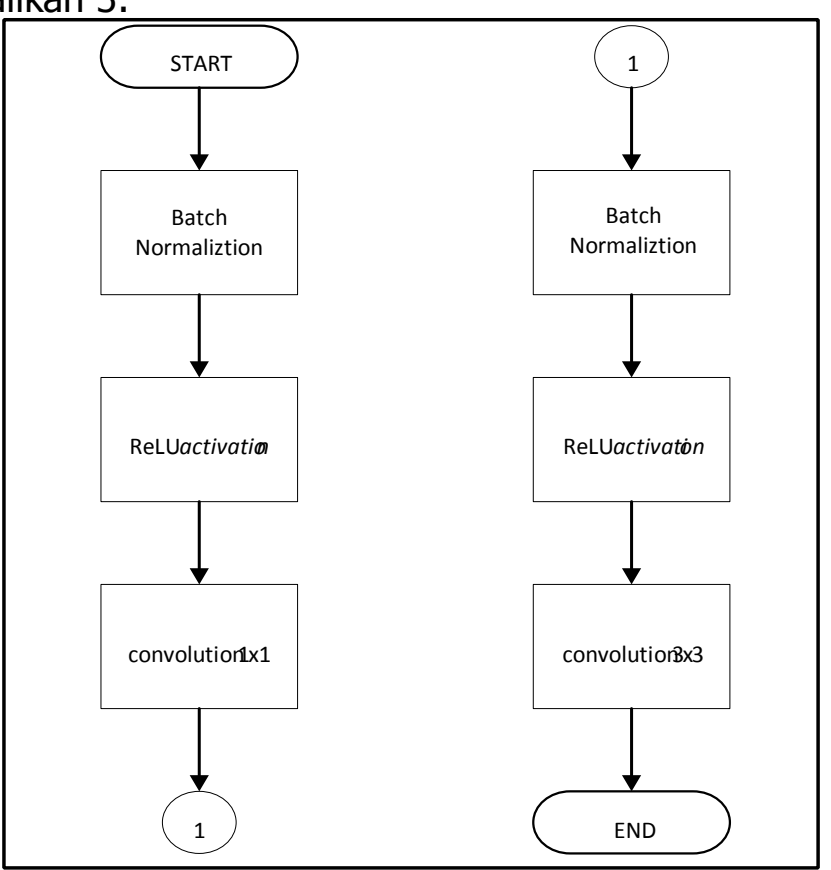

\section{Gambar 8. Flowchart Sub Proses Residual Block}

Pada Gambar 9 yang diilustrasikan sub proses transition layer terdapat operasi convolution $2 \times 2$ dan average pooling $1 \times 1$ dengan strides 2 , di proses ini transition layer terdapat 3 proses yaitu transition layer 1, transition layer 2, dan transition layer 3. Proses ini dilakukan sesudah proses Residual block agar proses transisi antara Residual block dengan transition layer. 


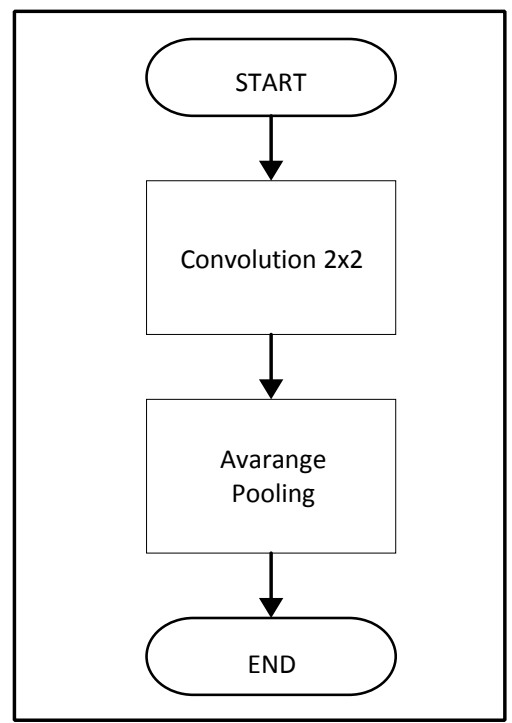

Gambar 9. Flowchart Sub Proses Transition Layer

\section{HASIL DAN PEMBAHASAN}

\subsection{Penggunaan Dataset}

Citra yang digunakan sebagai dataset merupakan citra yang didapat dari www.kaggle.com yang di upload oleh Paul Mooney pada tahun 2017. Data citra yang digunakan pada proses training, validation, dan testing merupakan citra yang berbeda. Banyak data latih dan data uji yang di gunakan bisa dilihat pada Tabel 1.

Tabel 1. Penggunaan Dataset

\begin{tabular}{|c|c|c|c|}
\hline Kelas & Training & Validation & Testing \\
\hline Pneumonia & 1.108 citra & 377 citra & 188 citra \\
\hline Normal & 1.320 citra & 317 citra & 158 citra \\
\hline
\end{tabular}

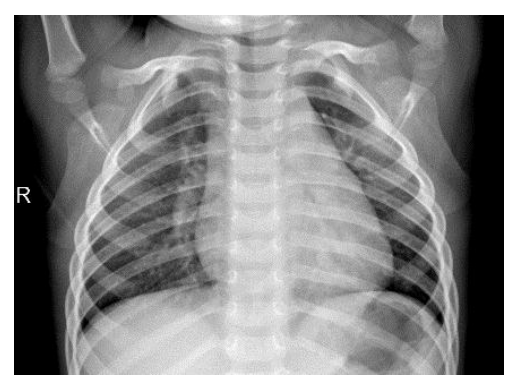

Gambar 10. Contoh Dataset

Sumber : (Paul Mooney, 2017)

Gambar 10 merupakan contoh citra dataset $x$-ray paru-paru manusia. Dimana citra dalam bentuk format .jpeg yang di dapat dari website kaggle. 


\subsection{Pengujian Sistem}

Pengujian dilakukan dengan menggunakan citra paru-paru $x$-ray, dengan menguji 3.468 citra. Dengan mengukur kinerja arsitektur ResNet-50 dan ResNet-152 menggunakan confusion matrix dimana akan mengukur kinerja sistem secara keseluruhan seperti accuracy, precision, recall, dan $f$-measure.

Pada Tabel 2 ditampilkan mengenai nilai training loss, training accuracy, validation loss, dan validation accuracy yang dihasilkan pada training yang memperlihatkan proses epoch. Terjadi penurunan pada loss tiap data training dengan data validation setiap proses penambahan epoch. Dan nilai akurasi data training dengan data validation terjadi kenaikan. Nilai pada epoch 1 ketika di training memiliki nilai training loss 0,4903 dan validation loss 0,6174 . Peningkatan accuracy terjadi pada epoch 3 mendapatkan nilai dengan training accuracy 0,8354 dan validation accuracy 0,8547. Pada Gambar 11 merupakan grafik hasil dari training data yang sudah dilakukan dengan menggunakan epoch 150 dengan model ResNet-152.

Tabel 2. Nilai Hasil Data Training

\begin{tabular}{|c|c|c|c|c|}
\hline \multicolumn{5}{|c|}{ ResNet-152 } \\
\hline $\begin{array}{c}\text { Epoch } \\
\text { Ke- }\end{array}$ & $\begin{array}{c}\text { Training } \\
\text { Loss }\end{array}$ & $\begin{array}{c}\text { Validation } \\
\text { Loss }\end{array}$ & Training Accuracy & Validation Accuracy \\
\hline 1 & 0.6206 & 0.7943 & 0.6173 & 0.4902 \\
\hline 2 & 0.5203 & 0.8391 & 0.8137 & 0.3910 \\
\hline 3 & 0.6133 & 0.8644 & 0.9418 & 0.3392 \\
\hline 4 & 0.6046 & 0.8627 & 0.9738 & 0.3282 \\
\hline 5 & 0.8706 & 0.8665 & 0.2964 & 0.3162 \\
\hline.$\cdot$ &.. &.$\cdot$ &.. & 0.3131 \\
\hline 146 & 0.7950 & 0.8652 & 0.4085 & 0.3081 \\
\hline 147 & 0.6148 & 0.8665 & 0.5963 & 0.3077 \\
\hline 148 & 0.8139 & 0.8685 & 0.3658 & 0.2918 \\
\hline 149 & 0.4607 & 0.8789 & 0.9611 & 0.2965 \\
\hline 150 & 0.5973 & 0.8805 & 0.5112 & \\
\hline
\end{tabular}
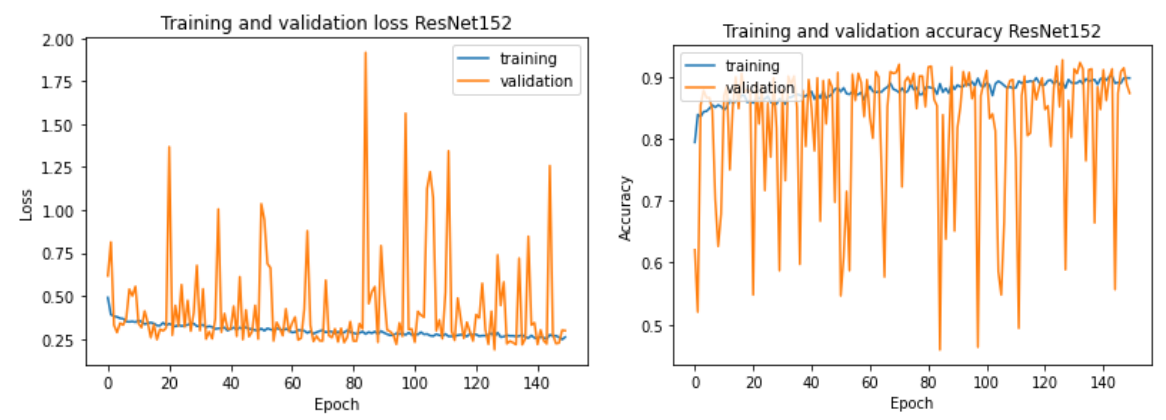

Gambar 11. Grafik Nilai Train Loss dan Valid Loss Training Data (Kanan). Grafik Nilai Train Accuracy dan Valid Accuracy Training Data (Kiri). Epoch 150, Leaning Rate 0.0001 , dan Optimizer Adam untuk ResNet-152. 


\subsection{Pengujian Kinerja Sistem}

Pengujian dilakukan dengan menggunakan citra paru-paru $x$-ray, dengan menguji 3.468 citra. Dengan mengukur kinerja arsitektur ResNet-50 dan ResNet-152 menggunakan confusion matrix dimana akan mengukur kinerja sistem secara keseluruhan seperti accuracy, precision, recall, dan f-measure. Bagian akurasi dari gambar yang tertangkap adalah tepat/signifikan. Sedangkan recall sangat penting untuk gambaran yang benar/signifikan yang diambil oleh framework. Sedangkan ketepatan atau accuracy adalah derajat kedekatan antara nilai yang diantisipasi dengan nilai yang sebenarnya. F-Measure adalah proporsi ketepatan pengujian dari estimasi akurasi dan recall (Pardede \& Husada, 2016). Pada Gambar 12. terdapat confusion matrix dari hasil klasifikasi pneumonia menggunakan ResNet50 dan ResNet-152.

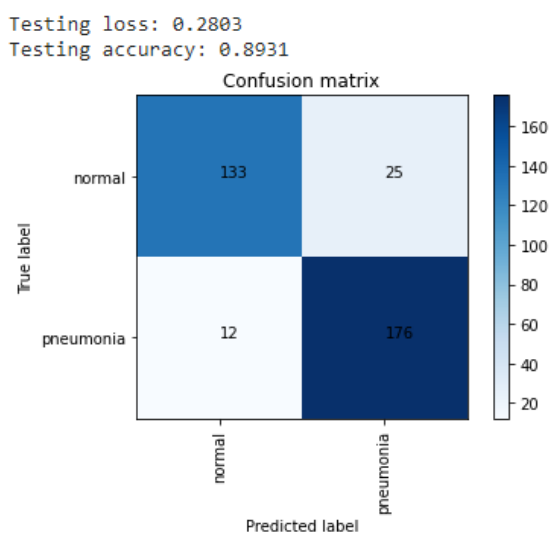

Gambar 12. Confusion Matrix Hasil Klasifikasi

Keterangan:

TN: 133, FN: 25,

FP: 12, TP: 176.

Untuk menghitung accuracy dengan Persamaan (1)

Accuracy $=\frac{\mathrm{TP}+\mathrm{TN}}{\mathrm{TP}+\mathrm{FP}+\mathrm{TN}+\mathrm{FN}}$
Accuracy $=\frac{176+133}{176+133+25+12}=0,893 * 100=89,3 \%$

Untuk menghitung precision dengan Persamaan (2)

$$
\text { Precision }=\frac{\mathrm{TP}}{\mathrm{TP}+\mathrm{FP}}
$$

Precision $($ pneumonia $)=\frac{176}{176+12}=0,936 * 100=93,6 \%$ 
Precision $($ normal $)=\frac{133}{133+25}=0,841 * 100=84,1 \%$

Untuk menghitung recall dengan Persamaan (3)

$$
\text { Recall }=\frac{\mathrm{TP}}{\mathrm{TP}+\mathrm{FN}}
$$

Recall $($ pneumonia $)=\frac{176}{176+25}=0,875 * 100=87,5 \%$

Recall $($ normal $)=\frac{176}{176+12}=0,917 * 100=91,7 \%$

Untuk menghitung F-Measure dengan Persamaan (4)

$$
f-\text { measure }=2 x \frac{(\text { Precission } x \text { Recall })}{(\text { Precission }+ \text { Recall })}
$$

$f-$ measure $($ pneumonia $)=2 x \frac{(0,936 \times 0,875)}{(0,936+0,875)}=0,904 * 100=90,4 \%$

$f-$ measure $($ normal $)=2 x \frac{(0,841 \times 0,917)}{(0,841+0,917)}=0,877 * 100=87,7 \%$

Tabel 3. Nilai Rata-Rata Accuracy, Precision, Recall, dan F-Measure Sistem dalam Mengidentifikasi Citra Pneumonia

\begin{tabular}{|c|c|c|c|c|c|}
\hline \multicolumn{6}{|c|}{ ResNet-152 } \\
\cline { 1 - 5 } No & Kelas & Precision & Recall & F-Measure & Accuracy \\
\hline 1 & Pnuemonia & $93,6 \%$ & $87,5 \%$ & $90,4 \%$ & \\
\cline { 1 - 5 } 2 & Normal & $84,1 \%$ & $91,7 \%$ & $87,7 \%$ & \multirow{2}{*}{$89,3 \%$} \\
\hline \multicolumn{2}{|c|}{ Rata - Rata } & $88,8 \%$ & $89,6 \%$ & $89 \%$ & \\
\hline
\end{tabular}

Hasil pengujian sistem pada resnet152 dalam mengidentifikasi pneumonia dimana didapatkan nilai rata-rata dari precision $88.8 \%$, recall $89.6 \%$, f-measure $89 \%$ dan accuracy $89,3 \%$ bisa dilihat pada Tabel 3.

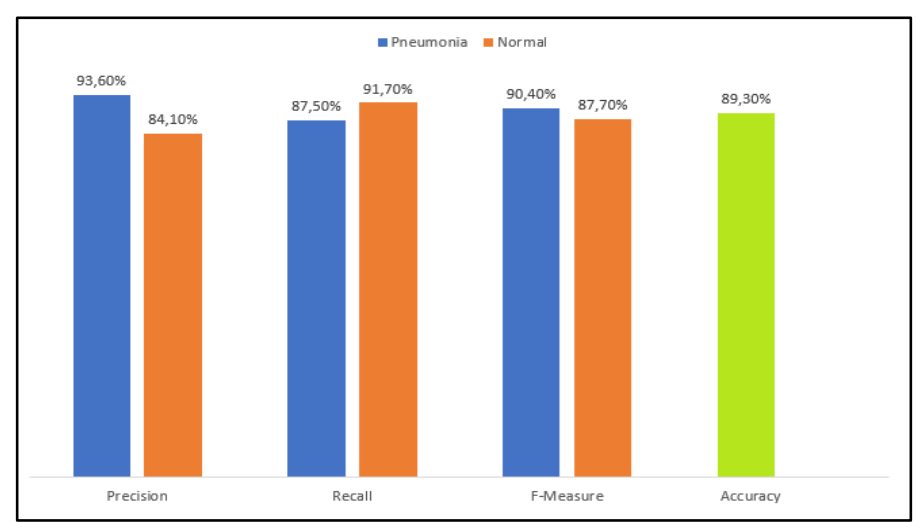

MIND - 179 
Perbandingan Metode Deep Residual Network 50 dan Deep Residual Network 152 Untuk Deteksi Penyakit Pneumonia pada Manusia

\section{Gambar 13. Grafik Rata-Rata Accuracy, Precision, Recall, dan F-Measure Identifikasi Citra Pneumonia}

Hasil pengujian sistem pada resnet152 dalam mengidentifikasi pneumonia dapat dilihat bentuk grafik nilai dari precision $84.1 \%$ dan $93.6 \%$, recall $87.5 \%$ dan $91.7 \%$, $f$-measure $90.4 \%$ dan 87,7\%, dan nilai accuracy mencapai 89,3\% bisa dilihat pada Gambar 13 .

Tabel 4. Tabel Perbandingan ResNet-50 dan ResNet-152 dengan Epoch 150

\begin{tabular}{|c|c|c|c|c|c|c|c|}
\hline \multirow{2}{*}{ ResNet } & \multirow{2}{*}{$\begin{array}{c}\text { Jumlah } \\
\text { Epoch }\end{array}$} & \multirow{2}{*}{$\begin{array}{c}\text { Learning } \\
\text { Rate }\end{array}$} & \multirow{2}{*}{ Optimizer } & \multicolumn{3}{|c|}{ Average } & \multirow{2}{*}{ Accuracy } \\
\cline { 5 - 7 } & & Precision & Recall & $\begin{array}{c}\text { F1- } \\
\text { Measure }\end{array}$ & \\
\hline 50 & 150 & 0,0001 & Adam & 0.88 & 0.89 & 0.88 & 0.887 \\
\hline 152 & 150 & 0,0001 & Adam & 0.89 & 0.90 & 0.89 & 0.893 \\
\hline
\end{tabular}

Pada pengujian ini dapat dilihat pada Tabel 4 dalam mengidentifikasi pneumonia dengan model ResNet-152 mendapatkan nilai rata-rata precision $89 \%$, recall $90 \%$ dan $f$-measure $89 \%$ dengan nilai accuracy 89,3\%. Dan model ResNet-50 mendapatkan nilai rata-rata precision $88 \%$, recall $89 \%$ dan $f$-measure $88 \%$ dengan nilai accuracy $88,7 \%$.

Tabel 5. Tabel Tabel Perbandingan ResNet-50 dan ResNet-152 dengan Epoch 100

\begin{tabular}{|c|c|c|c|c|c|c|c|}
\hline \multirow{2}{*}{$\begin{array}{c}\text { Jumlah } \\
\text { Epoch }\end{array}$} & \multirow{2}{*}{$\begin{array}{c}\text { Jumlah } \\
\text { Epoch }\end{array}$} & \multirow{2}{*}{$\begin{array}{c}\text { Learning } \\
\text { Rate }\end{array}$} & Optimizer & \multicolumn{3}{|c|}{ Average } & \multirow{2}{*}{ Accuracy } \\
\cline { 5 - 7 } & & & Precision & Recall & $\begin{array}{c}\text { F1- } \\
\text { Measure }\end{array}$ & \\
\hline 50 & 100 & 0,0001 & Adam & 0.88 & 0.88 & 0.88 & 0.881 \\
\hline 152 & 100 & 0,0001 & Adam & 0.85 & 0.87 & 0.86 & 0.861 \\
\hline
\end{tabular}

Pada pengujian ini dapat dilihat pada Tabel 5 dalam mengidentifikasi pneumonia dengan model ResNet-152 mendapatkan nilai rata-rata precision $85 \%$, recall $87 \%$ dan $f$-measure $86 \%$ dengan nilai accuracy $86,1 \%$. Dan model ResNet-50 mendapatkan nilai rata-rata precision $88 \%$, recall $88 \%$ dan $f$-measure $88 \%$ dengan nilai accuracy $88,1 \%$.

Tabel 6. Tabel Tabel Perbandingan ResNet-50 dan ResNet-152 dengan Epoch 50

\begin{tabular}{|c|c|c|c|c|c|c|c|}
\hline \multirow{2}{*}{$\begin{array}{c}\text { Jumlah } \\
\text { Epoch }\end{array}$} & \multirow{2}{*}{$\begin{array}{c}\text { Jumlah } \\
\text { Epoch }\end{array}$} & $\begin{array}{c}\text { Learning } \\
\text { Rate }\end{array}$ & Optimizer & \multicolumn{3}{|c|}{ Average } & \multirow{2}{*}{ Accuracy } \\
\cline { 5 - 7 } & & Precision & Recall & $\begin{array}{c}\text { F1- } \\
\text { Measure }\end{array}$ & \\
\hline 50 & 50 & 0,0001 & Adam & 0.88 & 0.89 & 0.89 & 0.887 \\
\hline 152 & 50 & 0,0001 & Adam & 0.83 & 0.85 & 0.84 & 0.841 \\
\hline
\end{tabular}

Pada pengujian ini dapat dilihat pada Tabel 6 dalam mengidentifikasi pneumonia dengan model ResNet-152 mendapatkan nilai rata-rata precision $83 \%$, recall $85 \%$ dan $f$-measure $84 \%$ dengan nilai accuracy $84,1 \%$. Dan model ResNet-50 mendapatkan nilai rata-rata precision $88 \%$, recall $89 \%$ dan $f$-measure $89 \%$ dengan nilai accuracy $88,7 \%$.

\section{KESIMPULAN}

Penelitian ini telah membandingkan metode CNN dari arsitektur ResNet-50 dengan ResNet152 untuk mengidentifikasi pneumonia. Dapat dilihat dari kedua metode tersebut bahwa ResNet-152 dapat mengungguli ResNet-50. Hasil tersebut menunjukkan nilai rata-rata 
terbaik accuracy $89,3 \%$, precision $88,8 \%$, recall $89,6 \%$, dan $f$-measure $89 \%$ dengan menggunakan epoch 150, learning rate 0,0001, dan optimizer Adam pada ResNet-152 setelah dilakukan pengujian dengan menguji mulai dari 50 epoch sampai dengan 150 dengan learning rate $(0,0001)$. Dapat diartikan pada dilihat dari penelitian ini bahwa banyaknya jumlah lapisan layer mempengaruhi kinerja dari metode tersebut. Nilai-nilai tersebut dipengaruhi oleh dataset dari citra training sebesar 2.428 citra, citra validation sebesar 694 citra, dan citra uji sebesar 346 citra. Berdasarkan hasil pengujian bahwa ukuran citra pneumonia pada manusia berbeda-beda dan masih dapat melakukan klasifikasi karena sistem dapat melakukan resize citra.

\section{DAFTAR RUJUKAN}

Eka Putra, W. S. (2016). Klasifikasi Citra Menggunakan Convolutional Neural Network (CNN) pada Caltech 101. Jurnal Teknik ITS, 5(1). https://doi.org/10.12962/j23373539.v5i1.15696

Feriawan, J., \& Swanjaya, D. (2020). Perbandingan Arsitektur Visual Geometry Group dan MobileNet Pada Pengenalan Jenis Kayu. Seminar Nasional Inovasi Teknologi, 185-190. https://proceeding.unpkediri.ac.id/index.php/inotek/article/view/84

Gao, X., Yan, X., Gao, P., Gao, X., \& Zhang, S. (2020). Automatic detection of epileptic seizure based on approximate entropy, recurrence quantification analysis and convolutional neural networks. Artificial Intelligence in Medicine, 102, 101711. https://doi.org/10.1016/j.artmed.2019.101711

Hakim, L. (2018). Seloka : Jurnal Pendidikan Bahasa dan Sastra Indonesia Learning Writing Explanatory Text Using Group Investigation Models Based on Learning Style. Seloka: Jurnal Pendidikan Bahasa Dan Sastra Indonesia, 73), 259-266.

Halprin Abhirawa, Jondri, A. A. (2017). Pengenalan Wajah Menggunakan Convolutional Neural Network. 4(3), 4907-4916.

He, K., Zhang, X., Ren, S., \& Sun, J. (2016). Deep Residual Learning for Image Recognition. 2016 IEEE Conference on Computer Vision and Pattern Recognition (CVPR), (pp. 770778). https://doi.org/10.1109/CVPR.2016.90

Jimmi Lin, H. I. (2021). Klasifikasi Pneumonia Pada Citra X-Rays Paru-Paru Menggunakan GLCM Dan LVQ 1,2. 1(2), 184-194.

LeCun, Y., Bengio, Y., \& Hinton, G. (2015). Deep learning. Nature, 521(7553), 436-444. https://doi.org/10.1038/nature14539

Maysanjaya, I. M. D. (2020). Klasifikasi Pneumonia pada Citra X-rays Paru-paru dengan 
Perbandingan Metode Deep Residual Network 50 dan Deep Residual Network 152 Untuk Deteksi Penyakit Pneumonia pada Manusia

Convolutional Neural Network. Jurnal Nasional Teknik Elektro Dan Teknologi Informasi, 9(2), 190-195. https://doi.org/10.22146/jnteti.v9i2.66

Munir, K., Elahi, H., Ayub, A., Frezza, F., \& Rizzi, A. (2019). Cancer Diagnosis Using Deep Learning: A Bibliographic Review. Cancers, 11(9). https://doi.org/10.3390/cancers11091235

Pardede, J., \& Husada, M. (2016). Comparison of VSM, GVSM, and LSI in information retrieval for indonesian text. Jurnal Teknologi, 78. https://doi.org/10.11113/jt.v78.8637

Russakovsky, O., Deng, J., Su, H., Krause, J., Satheesh, S., Ma, S., Huang, Z., Karpathy, A., Khosla, A., Bernstein, M., Berg, A. C., \& Fei-Fei, L. (2015). ImageNet Large Scale Visual Recognition Challenge. International Journal of Computer Vision, 115(3), 211-252. https://doi.org/10.1007/s11263-015-0816-y

Schmidhuber, Ai, S., Dalle, I., \& Galleria, S. (2014). Deep Learning in Neural Networks: An Overview. 1-88.

Vance, T. C., Merati, N., Yang, C., \& Yuan, M. (2016). Cloud computing for ocean and atmospheric science. OCEANS 2016 MTS/IEEE Monterey, 1-4. https://doi.org/10.1109/OCEANS.2016.7761270

Yousif, N., Cole, J., Rothwell, J. C., Diedrichsen, J., Zelik, K. E., Winstein, C. J., Kay, D. B., Wijesinghe, R., Protti, D. A., Camp, A. J., Quinlan, E., Jacobs, J. V, Henry, S. M., Horak, F. B., Jacobs, J. V, Fraser, L. E., Mansfield, A., Harris, L. R., Merino, D. M., ... Dublin, C. (2018). Implementasi Deep Learning Untuk Image Classification Menggunakan Algoritma Convolutional Neural Network (CNN) Pada Citra Wayang Golek. Journal of Physical Therapy Science, 9(1), 1-11. http://dx.doi.org/10.1016/j.neuropsychologia.2015.07.010 \%0Ahttp://dx.doi.org/10.1016/j.visres.2014.07.001\%0Ahttps://doi.org/10.1016/j.humo v.2018.08.006\%0Ahttp://www.ncbi.nlm.nih.gov/pubmed/24582474\%0Ahttps://doi.org/ 10.1016/j.gaitpost.2018.12.007\%0Ahttps: 